\title{
ВРАТА В ГЛОБАЛЬНОЕ ПРАВО: ГЛОБАЛЬНЫЕ ЦИФРОВЫЕ ПРАВА ЧЕЛОВЕКА
}

\author{
М. С. Бурьянов \\ Московский городской педагогический университет
}

\begin{abstract}
Аннотация: В статье исследованы принципы построения глобального права, сквозь призму цифровых технологий. Рассмотрены вопросы глобальных рисков индустрии 4.0. Предложено формирование глобальной цифровой нормативной системы.

Текст доклада автора на Общероссийской (национальной) научной конференции «Моисеевские чтения. Культура и гуманитарные проблемы современной цивилизации», которая состоялась 4-5 марта 2020 г. в Московском гуманитарном университете.

Ключевые слова: глобализация; глобальный риск; устойчивое развитие; глобальное управление; Четвертая промышленная революция; искусственный интеллект; глобальные цифровые права человека
\end{abstract}

\section{THE GATEWAY TO GLOBAL LAW: GLOBAL DIGITAL HUMAN RIGHTS}

\author{
M. S. Buryanov \\ Moscow City University
}

Abstract: The article explores the principles of building global law through the prism of digital technology. The issues of the global risks of industry 4.0 are considered. The formation of a global digital regulatory system is proposed.

The text of the author's speech at the All-Russian (National) Scientific Conference "Moiseev's Readings. The Culture and Humanitarian Issues of Modern Civilisation", which was held at Moscow University for the Humanities on 4-5 March, 2020.

Keywords: globalization; global risk; sustainable development; global governance; Fourth Industrial Revolution; artificial intelligence; global digital human rights

XXI век предоставил нам новые условия для развития, творчества, объединения, что, безусловно, сделало нашу жизнь более комфортной и насыщенной. Глобальный взгляд на взаимозависимую цивилизацию демонстрирует нам, что учеловека все меньше возможностей влиять на свою жизнь. Наши права, декларируемые со времен окончания двух мировых войн, нарушаются и концептуально устарели (Бурьянов, 2016ab), а волны нетерпимости разлагают общественные институты (Бурьянов, Кривенький, 2018). В условиях противоречивого развития глобальных процессов (Buryanov, 2018) и отнюдь не однозначной новой глобальной промышленной революции обостряется актуальность теоретико-правового исследования трансформаций публично-правовых институтов и цифровизации права.

Генеральный секретарь ООН А. Гутерриш, выступая на заседании Генассамблеи ООН с докладом об итогах работы организации в 2019 году и задачах на 2020 год, заявил, что видит четырех «всадников Апокалипсиса», угрожающих человечеству в XXI веке: это геостратегическое напряжение, рост глобального недоверия, климатический кризис и темная сторона цифрового мира. По его словам, нам необходимо обратить внимание на темную сторону цифровизации, ведь новые технологии развиваются до такой степени стремительно, что мы не успеваем не 
только отреагировать на них, но даже иногда осознать их сущность и ту агентность, которую они в себе несут. Помимо того, что цифровые технологии и искусственный интеллект несут колоссальные преимущества, они становятся инструментом диктата и контроля, вмешательства в частную жизнь, подстрекательства, манипуляции, распространения ложной информации, эксплуатации людей, а также совершения правонарушений. Среди прочего эксперты указывают на риски перехода власти торжеству сверхсильного искусственного интеллекта, который учтет всю летопись человеческой истории и может направить нас на аннигиляцию (Bostrom, 2014).

Цифровая революция создает радикально новые подходы по отношению к тому, что значит быть человеком. В данной статье представлено переосмысление прав человека в новом режиме их существования - глобальных тенденций и неуправляемой Четвертой промышленной революции. Без воздействия на описанные проблемы через рамки прав человека и правовой культуры мы потеряем контроль над скоростями цифровой глобализации, что может привести к планетарной катастрофе (Чумаков, 2018).

Силы технологической революции («цифровой революции») в некоторой мере распространились на систему права, как на национальном, так и на международном уровнях. Международные принципы создания информационного общества и подходы к его созданию определены Окинавской хартией глобального информационного общества (2000), Декларацией принципов «Построение информационного общества - глобальная задача в новом тысячелетии» (2003), Планом действий Тунисского обязательства (2005) и др.

Строя теоретическую систему глобального регулирования технологий, обозначим основные из них: искусственный интеллект и машинное обучение (Artificial intelligence and Deep learning), нейросетевые технологии, Интернет вещей (Internet of things), большие данные (Big Data), технологии на принципах распределенного реестра (Blockchain), аддитивное производство (Additive Manufacturing), «облачные» вычисления (Cloud computing), виртуальная и дополненная реальность (Augmented and additive reality), современные биоинженерные технологии (Biotech), «умные» комплексы и устройства (Smart everything), передовые материалы и энергетические технологии, автономные транспортные средства (Autonomous vehicles), квантовый компьютер (Quantum computing), системы кибербезопасности (Cybersecurity), технологии Solar Food, цифровые двойники (Digital twins), технологические алгоритмы (технологии нечетких систем, энтропийного управления, роевого интеллекта, эволюционных вычислений) (Schwab, 2017, 2018). Упомянем также цифровые технологические платформы и связанные с ними иные технологии. Все это создает технологическую основу для формирования принципиально новой нормативно-правовой среды регулирования (ставим акцент на международно-правовом поле регулирования) (Бурьянов, 2016а).

Итак, определим глобальные цифровые права человека, как полученные каждым с рождения (не дарованные публично-правовыми институтами, но несущими обязанность их реализовать), существенные возможности человека, 
которые устанавливаются и обеспечиваются системой форм международного и внутригосударственного права, дающие доступ к общественным благам, вытекающим из цифровых технологий. Глобальные цифровые права человека, как неуклонный базисный принцип цифровизации, раскрывающийся через систему принципов: технологии прав человека по замыслу, а не по умолчанию; первично формировать системы ориентированные на человека, а не технологии поддерживающие не вполне эффективные системы, склонные к цифровым диктатурам; расширять возможности инновациями, а не ограничивать их; приоритет прав человека и гуманистические ценности необходимо закладывать изначально на стадии разработки и проверять на всех этапах создания.

Итак, нам необходимо глобальное управление для незамедлительного ответа на глобальные риски цифровизации и иные угрозы (Бурьянов, 2019). Необходимо плавное урегулирование неравномерно растущих глобальных процессов и переход к устойчивому развитию цивилизации. Фундаментальный шаг в контроле неуправляемого роста - это создать глобальное право (Фархутдинов, 2004) для формирования будущего глобального управления в целях устойчивого развития (Чумаков, 2018) и реализации прав человека (Урсул, 2012). Глобальные цифровые права человека являются ядром современного понимания права, формирующегося глобального права и экономики знаний с целью максимального задействования человеческого капитала для ответов на глобальные проблемы.

Глобальные цифровые права человека - это шаг по направлению создания глобального права, который включает в себе ключевой ответ на вопрос, что значит быть человеком в современном мире глобализации 4.0. Необходимо закрепить в декларациях, а затем и в конвенциях о правах человека человеко-ориентированные принципы и нормы, каждому дающие доступ к цифровым технологиям вне зависимости от региона планеты.

\section{СПИСОК ЛИТЕРАТУРЫ}

Бурьянов, С. А.(2016а) Будущее международного правав условияхглобализации общественных отношений через призму творческого наследия Игоря Ивановича Лукашука // Евразийский юридический журнал. № 7 (98). С. 77-81.

Бурьянов, С. А. (2016b) Принцип неприменения силы или угрозы силой в условиях усиления глобальных процессов // Евразийский юридический журнал. № 9 (100). 2016. С. 8-15.

Бурьянов, М. С. (2019) Перспективы развития российской государственности в условиях современных глобальных процессов и вызовов // Актуальные проблемы глобальных исследований: Россия в глобализирующемся мире. Сб. мат-лов VI Bсероссийской научно-практической конференции, МГУ имени М. В. Ломоносова 4-6 июня 2019 г. / под ред. И. В. Ильина. М. : МООСИПНН Н. Д. Кондратьева. 466 с. C. 67-73.

Бурьянов, С. А., Кривенький А. И. (2018) Стратегические перспективы развития права и юридического образования в условиях современных глобальных процессов// Основные тенденции и перспективы развития современного права: Материалы ежегодной Международной научной конференции памяти 
профессора Феликса Михайловича Рудинского, 19 апреля 2018 года / под общ. ред. Д. А. Пашенцева. М. : МГПУ. 505 с. С. 247-251.

Урсул, А. Д. (2012) Глобализация права и глобальное право: концептуальнометодологические проблемы // Право и политика. № 8. С. 1284-1297.

Фархутдинов, И. 3. (2004) Международное или глобальное право // Юристмеждународник. № 4. С. 15-23. $512 \mathrm{c}$.

Чумаков, А. Н. (2018) Глобальный мир: столкновение интересов. М. : Проспект.

Bostrom, N. (2014) Superintelligence: Paths, Dangers, Strategies Reprint Edition. Oxford University Press. $352 \mathrm{p}$.

Buryanov, S. A. (2018) State Worldview Neutrality in the Context of Deteriorating Imbalances in Globalization. Amsterdam. 228 p.

Schwab, K. (2017) The Fourth Industrial Revolution. Crown Business. New York. $192 \mathrm{p}$.

Schwab, K. (2018) Shaping the Fourth Industrial Revolution. Portfolio Penguin. 288 p. Дата поступления: 30.03.2020 г.

Бурьянов Максим Сергеевич - студент 2 курса института права и управления Московского городского педагогического университета. Тел.: +7 (495) 470-48-84. Эл. адрес: maksim.burianov@yandex.ru

Buryanov Maksim Sergeyevich, Student, Institute of Law and Management, Moscow City University. Tel.: +7 (495) 470-48-84. E-mail: maksim.burianov@yandex.ru

\section{Для цитирования:}

Бурьянов М. С. Врата в глобальное право: глобальные цифровые права человека // Научные труды Московского гуманитарного университета. 2020. №2. C. 63-66. DOI: 10.17805/ trudy.2020.2.11 